\title{
STARCH, SUGAR, AMYLASE AND INVERTASE ACTIVITY IN THE GERMINATING SEEDS OF MODERN WHEAT VARIETIES
}

\author{
M.A. KASHEM ${ }^{1}$, NILUFA SULTANA, S.C. SAMANTA ${ }^{2}$ and A.M.A. KAMAL \\ 1 Department of Biochemistry and Department of Agronomy, Bangladesh \\ Agricultural University, Mymensingh, Bangladesh. \\ 2 Department of Agronomy, Patuakhali Agricultural College, Patuakhali, \\ Bangladesh.
}

(Received: 21 September 1994; accepted: 09 February 1995)

\begin{abstract}
Amylase and invertase activity was studied in germinating seeds of eight modern wheat varieties (Akbar, Aghrani, Ananda, Balaka, Barkat, Kanchan, Pavon and Sonalika). Activities of the enzymes were low at the initial stages and thereafter significantly increased and further decreased at later stages of germination. The peak amylase and invertase activity was observed at 60 and $72 \mathrm{~h}$ of incubation for germination respectively. Protein content was significantly increased with the period of germination. Starch depletion was slow initially and thereafter fast. The degradation rate of starch was about $60 \%$ and accumulation of sugar was 4 times higher in seeds at $96 \mathrm{~h}$ of germination over the ungerminated seeds.
\end{abstract}

Keywords: Amylase activity, germinating seeds, invertase activity, wheat.

\section{INTRODUCTION}

Stored starch plays an important role in the development of embryo during germination of seeds. The increase in metabolic activity in germinating seeds is due to the induction of some of the hydrolytic enzymes. ${ }^{1,2}$ Amylase and invertase are two important hydrolytic enzymes that increase sugars in germinating seeds of rice. ${ }^{3}$ Starch is hydrolysed by the amylolytic enzymes to provide substrate and energy sources for the embryo during germination. The amylase activity was slow up to $48 \mathrm{~h}$ after germination. ${ }^{4}$ The simultaneous increase in soluble sugars and amylase activity and decrease in starch in Vicia faba could be due to faster breakdown of starch. ${ }^{5}$ The amylolytic breakdown of storage carbohydrates is also important in the brewery industry. ${ }^{6}$

The present study reports the activities of two hydrolytic enzymes and the degradation of starch during a $4 \mathrm{~d}$ period of germination of seeds of modern wheat varieties.

\section{METHODS AND MATERIALS}

Seeds of eight Bangladesh wheat varieties viz. Aghrani, Akbar, Ananda, Balaka, Barkat, Kanchan, Pavon and Sonalika were obtained from the Agronomy Department of the Bangladesh Agricultural University (BAU). The experiment was conducted in a split plot design with varieties in the main plots and varying periods of incubation $(0,12,24,36,48,60,72,84$ and $96 \mathrm{~h})$ in subplots. Seeds were soaked in distilled water and allowed to germinate from $0 \mathrm{~h}$ (dry seed) to $96 \mathrm{~h}$. 
Samples were taken every $12 \mathrm{~h}$. Two grams of seeds. were ground in $10 \mathrm{ml}$ of $0.2 \mathrm{M}$ acetate buffer ( $\mathrm{pH} 4.8$ ). The suspension was centrifuged at $2000 \mathrm{rpm}$ for $5 \mathrm{~min}$ to remove cell debris. The supernatent was again centrifuged at $10478 \mathrm{~g}$ at $0^{\circ} \mathrm{C}$ for $55 \mathrm{~min}$ and made up to $20 \mathrm{ml}$ with buffer. Protein was estimated by absorption at 260 and $280 \mathrm{~nm}^{7}$

For reducing sugars, two grams of seeds were boiled with $80 \%$ ethanol. From the alcohol-insoluble residue, starch was estimated colorimetrically, with anthrone reagent. $^{8}$

The specific activities of amylase and invertase were assayed according to the method of Mahadevan and Sridhar ${ }^{9}$ and reducing sugar contents were estimated by Nelson's modification of Somogyi's method. ${ }^{10}$

The data of the experiment were analyzed statistically and the mean differences were adjudged by the LSD test at 5\% level of significance.

\section{RESULTS AND DISCUSSION}

Germination rate of eight varieties was variable (Table 1). Germination started at $36 \mathrm{~h}$ and gradually increased up to $96 \mathrm{~h}$. At $36 \mathrm{~h}$ of incubation, Balaka, Barkat and Sonalika showed the higher percentage of germination followed by other varieties. At 96 h of incubation, the varieties completed about $95 \%$ germination.

Table 1: Germination percent of eight wheat varieties at different hours of incubation.

\begin{tabular}{llllllllll}
\hline $\begin{array}{l}\text { Hours (h)/ } \\
\begin{array}{l}\text { Varieties } \\
\text { v) }\end{array}\end{array}$ & 0 & 12 & 24 & 36 & 48 & 60 & 72 & 84 & 96 \\
\hline Aghrani & 0 & 0 & 0 & 8.3 & 15 & 60 & 90 & 94 & 99 \\
Akbar & 0 & 0 & 0 & 3 & 24 & 55 & 73 & 80 & 90 \\
Ananda & 0 & 0 & 0 & 6 & 20 & 30 & 40 & 58 & 90 \\
Balaka & 0 & 0 & 0 & 15 & 16 & 48 & 74 & 90 & 97 \\
Barkat & 0 & 0 & 0 & 12 & 14 & 18 & 38 & 67 & 89 \\
Kanchan & 0 & 0 & 0 & 6 & 15 & 20 & 32 & 57 & 80 \\
Pavon & 0 & 0 & 0 & 8 & 25 & 34 & 45 & 50 & 84 \\
Sonalika & 0 & 0 & 0 & 10 & 45 & 70 & 87 & 96 & 98 \\
\hline
\end{tabular}

Table 2 shows the variation in amylase activity between wheat strains during germination. Amylase activity was the highest in Balaka which was similar to Barkat, Pavon and Aghrani and lowest in Akbar. Mean amylase 
activity was significantly increased up to $60 \mathrm{~h}$ of incubation and declined thereafter. The activity was about 5 times higher at the peak and 3 times higher at $96 \mathrm{~h}$ compared to ungerminated seeds. Maximal amylase activity in Aghrani occurred at 48-60 h. In Pavon, maximal amylase activity was achieved in the period 36-72 $\mathrm{h}$. The results are in agreement with the finding of Thimmaiah ${ }^{11}$ who found that amylase activity was variable among the wheat cultivars and the activity was low at initial stages and increased steeply and further decreased at later stages of germination. Amylase activity increased up to $120 \mathrm{~h}$ of germination in cotton seeds. ${ }^{4}$

Table 2: Amylase activity of eight wheat varieties at different hours of germination (units of reducing sugar/h/mg of protein).

\begin{tabular}{lllllllllll}
\hline $\begin{array}{l}\text { Hours (h)/ } \\
\text { Varieties }\end{array}$ & 0 & 12 & 24 & 36 & 48 & 60 & 72 & 84 & 96 & Mean \\
$(\mathrm{v})$ & & & & & & & & & & \\
\hline
\end{tabular}

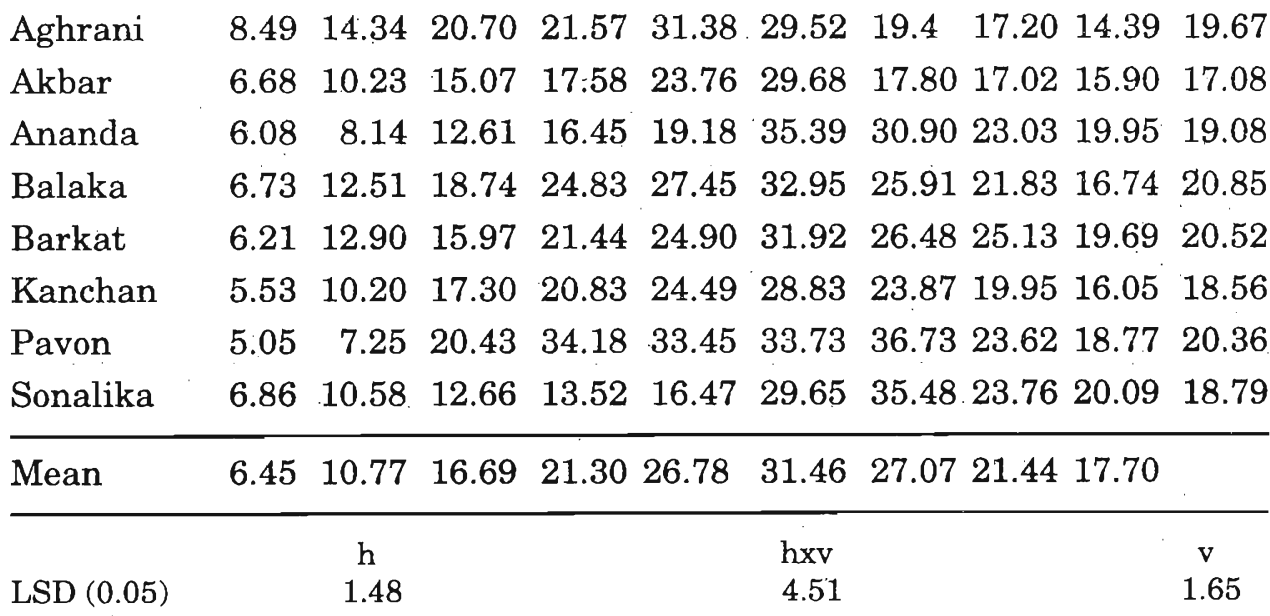

Invertase activity differed between varieties and with time after germination (Table 3). The mean invertase activity was high in Barkat, Akbar, Kanchan, Pavon, Sonalika and Ananda and lowest in Balaka. Invertase activity increased up to $72 \mathrm{~h}$ and thereafter declined. There were varietal differences in the time required to achieve peak invertase activity. Takeo Nomura et al. ${ }^{12}$ found that invertase activity in germinating rice seed also showed a similar peak in activity. The soluble protein contents of the eight varieties were not similar (Table 4). The protein content was highest in Kanchan ( $52 \mathrm{mg}$ protein per gram seeds ) and in Balaka (up to $45 \mathrm{mg}$ protein per gram of seeds). The rest of the varieties ranked in intermediate position. Soluble protein contents increased with germinating time. The soluble protein contents were found to be different in cotton varieties ${ }^{13}$ and to increase during germination of rice seeds. ${ }^{2}$ 
Table 3: Invertase activity of eight wheat varieties at different hours of germination (units of reducing sugar/h/mg of protein).

$\begin{array}{lllllllllll}\text { Hours (h) } / & 0 & 12 & 24 & 36 & 48 & 60 & 72 & 84 & 96 & \text { Mean }\end{array}$

Varieties

(v)

\begin{tabular}{lrrrrrrrrrr}
\hline Aghrani & 4.59 & 5.94 & 6.57 & 7.54 & 8.55 & 9.57 & 9.78 & 10.70 & 10.34 & 8.18 \\
Akbar & 4.92 & 5.92 & 6.40 & 8.25 & 12.36 & 12.90 & 14.18 & 13.38 & 8.54 & 9.65 \\
Ananda & 5.24 & 6.48 & 7.73 & 8.65 & 8.83 & 12.90 & 13.31 & 11.50 & 8.26 & 9.21 \\
Balaka & 4.47 & 5.30 & 6.56 & 6.83 & 8.22 & 10.15 & 9.41 & 8.68 & 7.36 & 4.44 \\
Barkat & 4.90 & 6.41 & 8.74 & 9.77 & 11.30 & 13.09 & 14.56 & 12.04 & 10.34 & 10.13 \\
Kanchan & 4.36 & 5.38 & 7.38 & 7.86 & 10.61 & 13.31 & 15.01 & 12.66 & 9.59 & 9.57 \\
Pavon & 4.97 & 6.16 & 6.71 & 9.09 & 10.60 & 12.34 & 15.15 & 10.70 & 8.56 & 9.36 \\
Sonalika & 3.72 & 6.31 & 6.98 & 7.64 & 10.42 & 11.14 & 12.25 & 10.39 & 8.94 & 8.64 \\
\hline Mean & 4.65 & 5.99 & 7.13 & 8.20 & 10.1 & 11.93 & 12.96 & 11.26 & 8.99 \\
\hline \multicolumn{3}{c}{} & \multicolumn{3}{c}{$\mathrm{h}$} & & & $\mathrm{hxv}$ & & \multicolumn{4}{c}{$\mathrm{v}$} \\
LSD (0.05) & \multicolumn{3}{c}{1.12} & & & 3.11 & & & 0.99 &
\end{tabular}

Table 4: Soluble protein of eight wheat varieties at different hours of germination (mg of protein/gram of wheat).

\begin{tabular}{lllllllllll}
\hline Hours $(\mathrm{h}) /$ & 0 & 12 & 24 & 36 & 48 & 60 & 72 & 84 & 96 & Mean
\end{tabular}

Varieties

(v)

$\begin{array}{lllllllllll}\text { Aghrani } & 31.30 & 39.52 & 40.41 & 40.97 & 42.45 & 42.50 & 42.85 & 43.59 & 44.85 & 40.94\end{array}$ $\begin{array}{lllllllllll}\text { Akbar } & 29.27 & 36.28 & 39.41 & 40.48 & 42.03 & 43.58 & 45.39 & 46.56 & 47.43 & 41.16\end{array}$ $\begin{array}{lllllllllll}\text { Ananda } & 27.13 & 34.63 & 34.98 & 39.39 & 40.63 & 44.74 & 45.95 & 46.56 & 48.07 & 40.23\end{array}$ $\begin{array}{lllllllllll}\text { Balaka } & 27.46 & 36.67 & 38.80 & 41.14 & 42.21 & 43.17 & 43.59 & 43.31 & 45.20 & 40.17\end{array}$ $\begin{array}{lllllllllll}\text { Barkat } & 31.30 & 36.32 & 37.36 & 39.13 & 41.70 & 42.56 & 45.11 & 44.86 & 54.29 & 41.63\end{array}$ $\begin{array}{lllllllllll}\text { Kanchan } & 30.03 & 37.37 & 41.97 & 42.40 & 48.34 & 46.83 & 46.91 & 49.61 & 51.98 & 43.94\end{array}$ $\begin{array}{llllllllllll}\text { Pavon } & 26.78 & 35.58 & 39.98 & 41.67 & 43.28 & 43.07 & 47.38 & 48.14 & 48.89 & 41.64\end{array}$ $\begin{array}{lllllllllll}\text { Sonalika } & 28.45 & 31.41 & 39.00 & 41.98 & 40.73 & 43.79 & 46.23 & 51.29 & 53.72 & 41.84\end{array}$ $\begin{array}{llllllllll}\text { Mean } & 28.97 & 35.97 & 38.99 & 40.89 & 42.67 & 43.78 & 45.43 & 46.74 & 49.30\end{array}$

\begin{tabular}{lccc}
\hline & $\mathrm{h}$ & $\mathrm{hxv}$ & $\mathrm{v}$ \\
$\operatorname{LSD}(0.05)$ & 1.74 & 5.68 & 2.95
\end{tabular}


The breakdown of starch in the varieties is shown in Table 5. The rate of degradation was variable. Starch depletion in the varieties was up to $60 \%$ at $96 \mathrm{~h}$ of incubation. The accumulation of reducing sugars was variable among varieties and period on incubation ( Table 6 ). Sonalika showed highest amount of sugar which was identical with Kanchan and Balaka and the lowest was in Akbar. The sugar content was significantly increased with the period of germination. The rate of accumulation of sugars was higher in Balaka, Barkat at $96 \mathrm{~h}$ and it was 5 times higher than the ungerminated seeds. These results are in agreement with those observed by Dhanunjayanath ${ }^{14}$ who found $74 \%$ depletion of starch and 4 times increase of sugar at $96 \mathrm{~h}$ over the zero period of germination in horse gram.

Table 5: Percent starch contents of eight wheat varieties at different hours of germination

\begin{tabular}{lllllllllll}
\hline $\begin{array}{l}\text { Hours (h)/ } \\
\text { Varieties } \\
(\mathrm{v})\end{array}$ & 0 & 12 & 24 & 36 & 48 & 60 & 72 & 84 & 96 & Mean \\
\hline
\end{tabular}

\begin{tabular}{|c|c|c|c|c|c|c|c|c|c|c|}
\hline Aghrani & 60.31 & 58.95 & 55.53 & 50.54 & 44.79 & 39.84 & 33.53 & 29.77 & 23.87 & $44: 17$ \\
\hline Akbar & 56.24 & 53.88 & 51.22 & 47.50 & 43.93 & 38.37 & 34.51 & 28.11 & 23.65 & 41.99 \\
\hline Ananda & 56.84 & 54.58 & 50.13 & 46.40 & 42.70 & 39.65 & 33.75 & 29.11 & 23.65 & 41.90 \\
\hline Balaka & 57.79 & 55.65 & 51.52 & 47.55 & 44.19 & 38.49 & 34.10 & 28.12 & 23.22 & 42.29 \\
\hline Barkat & 58.77 & 55.99 & 52.36 & 47.56 & 42.13 & 37.25 & 32.09 & 27.89 & 23.34 & 41.93 \\
\hline Kanchan & 56.55 & 54.59 & 50.82 & 45.91 & 41.86 & 37.45 & 34.40 & 29.81 & 25.26 & \\
\hline Pavon & 58.56 & 57.09 & 51.66 & 46.62 & 41.63 & 37.89 & 33.59 & 29.49 & 24.33 & 42.3 \\
\hline Sonalika & 61.86 & 59.23 & 53.85 & 48.73 & 44.15 & 37.86 & 32.86 & 28.19 & 23.16 & 43.3 \\
\hline Mean & 58.36 & 56.24 & 52.21 & 47.60 & 43.17 & 38.41 & 33.60 & 28.81 & 23.81 & \\
\hline $\operatorname{LSD}(0.05)$ & & 0 . & 91 & & & $\begin{array}{l}\text { hxv } \\
3.49\end{array}$ & & & $\begin{array}{c}\mathrm{v} \\
3.51\end{array}$ & \\
\hline
\end{tabular}

From the results, it seems that the cultivars showed variability with respect to the level of hydrolytic enzymes. This could be ascribed to their growth rate and varietal genetic difference. The enzyme activity was significantly low in dry seeds compared to seedling due to residual enzyme synthesis during maturation of seed before harvest and the de novo synthesis of the enzymes during germination. The accumulation of more sugars at later stage was due to the breakdown of starch by the activity of hydrolytic enzymes. 
Table 6: Reducing sugar contents of eight wheat varieties at different hours of germination (mg/gm of wheat).

\begin{tabular}{lllllllllll}
\hline Hours $(\mathrm{h}) /$ & 0 & 12 & 24 & 36 & 48 & 60 & 72 & 84 & 96 & Mean.
\end{tabular}

Varieties

(v)

\begin{tabular}{|c|c|c|c|c|c|c|c|c|c|c|}
\hline Aghrani & 1.85 & 1.55 & 2.22 & 2.80 & 3.41 & 5.89 & 7.42 & 7.62 & 8.38 & 4.57 \\
\hline Akbar & 1.61 & 1.79 & 1.98 & 2.51 & 2.93 & 3.27 & 3.73 & 5.93 & 7.28 & 3.45 \\
\hline Ananda & 1.71 & 1.88 & 2.12 & 2.67 & 3.31 & 4.27 & 4.78 & 5.39 & 6.00 & 3.57 \\
\hline Balaka & 1.69 & 2.92 & 3.37 & 3.93 & 4.82 & 5.92 & 6.52 & 7.62 & 8.29 & 5.01 \\
\hline Barkat & 2.10 & 2.45 & 2.88 & 3.53 & 3.90 & 4.53 & 5.29 & 6.70 & 7.25 & 4.29 \\
\hline Kanchan & 2.57 & 3.66 & 4.28 & 5.27 & 5.80 & 6.43 & 6.77 & 7.17 & 7.17 & 5.52 \\
\hline Pavon & 2.48 & 2.99 & 3.28 & 3.53 & 3.70 & 4.13 & 4.82 & 5.96 & 7.37 & 4.25 \\
\hline Sonalika & 3.03 & 3.88 & 4.43 & 5.28 & 6.05 & 6.41 & 6.86 & 7.19 & 7.84 & 5.66 \\
\hline Mean & 2.13 & 2.64 & 3.07 & 3.70 & 4.24 & 5.11 & 5.76 & 6.70 & 7.51 & \\
\hline $\operatorname{LSD}(0.05)$ & & $\begin{array}{c}\mathrm{h} \\
0.27\end{array}$ & & & & 38 & & & $\begin{array}{c}\mathrm{v} \\
0.58\end{array}$ & \\
\hline
\end{tabular}

\section{References}

1. Sharma A. \& Sengupta U.K. (1987). Changes in protease and alpha amylase activity in germinating seeds of groundnut. Indian Journal of Plant Physiology 30(2): 176-182.

2. Sheoran I.S. (1980). Changes in amylase during germination and early seedling growth of mung bean (Vigna radiata (L.) Wilezek) under different salts. Indian Journal of Plant Physiology 23(2):169-173.

3. Mitra S., Ghosh B. \& Sircar S.M. (1976). Physiological changes in rice seed during the early stage of germination. Indian Journal of Agricultural Sciences 63(7): 426-428.

4. Zodape S.T., Chauhan V.D. \& Gomkale S.D. (1993). Biochemical changes during early seedling growth of upland cotton (Gossypium hirsutum). Indian Journal of Agricultural Sciences 63(7): 426-428.

5. Akhter N. , Bashar S.A.M.K. \& Gomes J. (1991). Amylase activities in cotyledons of germinating Psophocarpus tetragonolobus and Vicia faba L. Bangladesh Journal of Scientific Research 9(2): 209-210. 
6. Akazawa T., Mitsui T. \& Hayashi M. (1988). The Biochemistry of Plants. Vol. 14, Academic Press, Inc. New York U.S.A. pp. 465-492.

7. Warburg O. \& Christian W. (1942). Isolation and crystallization of enolase. Zeitschrift Fuer Biochemie 310: 384-421.

8. Dubois M.K., Gilles J.K., Hamilton P.A., Rebers P.A. \& Smith F. (1951). A colorimetric method for the determination of sugars. Nature 168: 167.

9. Mahadevan A. \& Sridhar R. (1982). Amylase and invertase assay. In: Methods in Physiological Plant Pathology. 2nd. ed. Sivakami Publication. 40.1 Main Road, Indira Nagar, Madras 600 020. pp. 57-58.

10. Nelson N. (1944). A photometric adaptation of the Somogyi method for the determination of glucose. Journal of Biological Chemistry 153: 375-380

11. Thimmiah S.K. (1989). Changes in amylase activity of wheat during germination. Indian Journal of Plant Physiology 32(3): 258-260.

12. Takeo N., Yasuhiro K. \& Akazawa T. (1969). Enzymic mechanism of starch breakdown in germinating rice seeds: ii. Scutellum as the site of sucrose synthesis. Plant Physiology 44: 765-769.

13. Gupta M.P. (1991). Amylase activity in cotton. Indian Journal of Agricultural Research 25(3): 141-148.

14. Dhanunjayanath V., Karunagaran D. \& Rao P.R. (1993). Effect of fluoride on germination and starch mobilization of horse gram seeds. Indian Journal of Plant Physiology 36(2): 131-133. 